\title{
A Descriptive Analysis of Learning Motivation Taken From Laskar Pelangi Novel
}

\author{
Nur Muthmainnah \\ English Department of Educational Faculty \\ State Institute for Islamic Studies \\ STAIN Salatiga \\ itsenough88@yahoo.com
}

\begin{abstract}
This paper informs us some motifs that motivate someone learning something taken from Laskar Pelangi novel. There are four research problems proposed of Laskar Pelangi novel; what are the literary elements of Laskar Pelangi novel; what are the motivations in learning presented in the novel of Laskar Pelangi; what are the reasons of Andrea Hirata took the motivation of learning in Laskar Pelangi novel; what are the implications of Laskar Pelangi novel toward its readers. This research uses descriptive research in analyzing, collecting the data. After analyzing the novel Laskar Pelangi the writer draws some conclusions as follows: the novel uses some figurative language to express some expressions and describe something; its main character is Ikal. Laskar Pelangi tells us some motifs of learning. The motivations which are pointed out are to enrich knowledge, to reach dream, to win a competition, and so on. The reason Andrea Hirata took learning motivation as the theme of Laskar Pelangi novel are to break Melayunese stereotype, to motivate all learner to be motivated in learning, and so on. The implication of Laskar Pelangi story toward its reader are Laskar Pelangi story motivated reader to study abroad, Laskar Pelangi teaches reader to admire the life.
\end{abstract}

Keywords: learning motivation, Laskar Pelangi, literary elements

\begin{abstract}
Abstrak
Penelitian ini memberitahukan kepada kita tentang dorongan yang memotivasi seseorang untuk mempelajari sesuatu yang diambil dari novel Laskar Pelangi. Ada empat permasalahan riset yang diajukan dari novel Laskar Pelangi; apa unsur-unsur sastra yang ada dalam novel Laskar Pelangi; apa motivasi belajar yang diperkenalkan dalam novel Laskar
\end{abstract}


Pelangi; apakah alasan bagi Andrea Hirata memilih motivasi belajar dalam novel Laskar Pelangi; apa implikasi novel Laskar Pelangi terhadap para pembacanya. Riset ini menggunakan jenis riset deskriptif dalam meneliti dan mengumpulkan data. Setelah meneliti novel Laskar Pelangi, penulis menarik beberapa kesimpulan sebagai berikut: novel tersebut menggunakan beberapa perlambang bahasa (majas) untuk menyatakan beberapa ungkapan dan menggambarkan sesuatu; karakter utamanya adalah Ikal. Laskar Pelangi menceritakan kepada kita tentang dorongan belajar. Motivasi yang dimaksud adalah untuk memperkaya pengetahuan, untuk meraih mimpi, untuk memenangkan suatu kompetisi, dan seterusnya. Alasan Andrea Hirata memilih motivasi belajar sebagai tema novel Laskar Pelangi adalah untuk mematahkan pandangan negatif tentang orang Melayu, untuk memotivasi semua pelajar agar termotivasi dalam belajar, dan lain-lain. Implikasi cerita Laskar Pelangi terhadap pembacanya adalah cerita Laskar Pelangi mendorong pembaca untuk belajar ke luar negeri, Laskar Pelangi mengajari pembaca untuk mengagumi kehidupan.

Kata Kunci: Motivasi Belajar, Laskar Pelangi, Unsur-Unsur Sastra

\section{Introduction}

Learning is not limited in some fields of study; we can learn everything from our life. Learning must not take place in formal area, thus learning can be conducted everywhere formally and informally. We can learn from everything around us, because getting knowledge is not bounded with the explanation from teacher in a class, everything can be taken as source when we learn something. For example, a child learns how to respect each other. He does not get it from his teacher's explanation but he finds it from imitating how his family behaves.

Dealing with motivation, everybody has different motif to do learning. Everything can be a reason from someone to learn something that motivates him to learn on and on. Even, because of a girl whom a man loves, can motivate a man to do or learn. Motivation can also be found from any 
sources. From paying attention to his environment, someone can be motivated, such as, Andrea Hirata, an author of Laskar Pelangi novel; he could reach his dream studying in France because of his friend motivations, Lintang. His environment also encourages him to write Laskar Pelangi novel that describe his environment and his struggle to study. Everything can be a motivation to do something.

Laskar Pelangi novel talks about the struggle of ten children called as Laskar Pelangi to get knowledge in Muhammadiyah Elementary School, the worst scholl in their village. They faced many obstacles to reach their ambitions, from the distance from their house to their school was so far, many hindrances on the way to school such as big crocodile that spoiled their trip, or very limited school facilities, those do not hamper them not to give up learning and reaching their ambition.

Novel can motivate someone to do something. Moreover Laskar Pelangi, which has power to encourage someone to realize that there is is the worth condition from us, but Laskar Pelangi members condition did not hamper Laskar Pelangi student to fight their spirit reaching their ambition. Because of its great power which comes from this novel to motivate someone to learn, the writer interested in conducting a research with the problems that will be discussed are as follows; (1) what are the motivations in learning presented in the novel of Laskar Pelangi?;(2) what are the reasons of Andrea Hirata took the motivation of learning in Laskar Pelangi novel?;(3) what are the implications of Laskar Pelangi novel toward its readers?.

\section{Motivation}

Based on Longman Dictionary of Contemporary English, motivation is eagerness and willingness to do something without needing to be told or forced to do it (Longman team, 2003: 1071). 


\section{Learning}

Taken from Oxford Advance Learner's Dictionary of Current English, learning is that gain knowledge of or skill in by study, practice of being taught (Hornby, 1987: 481). Gage said that learning can be defined with a process where an organism has changed their behavior because of their experiences (Dahar, 1989: 11).

Novel

Novel is story in prose, long enough to fill one or more volumes about either imaginary or historically people (Longman Team, 2003: 1309).

\section{Laskar Pelangi}

Laskar Pelangi is the first novel of Laskar Pelangi tetra-logy which is written by Andrea Hirata. It was published firstly in 2005 by Bentang Pustaka Press. This novel contains 534 paged. This novel tells about a heroic story of ten childrem called as Laskar Pelangi who came from poor family. Although, their school were still spirit to study. Their school was only facilitated with an unclosed cupboard, chairs and tables which in bad condition, and old blackboard. With all of their limitations they never give up and always keep fight their spirit in learning. By their spirit that they had, Laskar Pelangi could compete with other children who were richer in some competition which was held by district government and they won it that made their school to be known with others.

\section{Research method and procedures}

The type of research includes descriptive analysis research. This type of research is conducted by describing facts then followed by analysis. Then, the research object of this study is not only the main character of this novel but also all of other nine children as the actors in Laskar Pelangi. 
Furthermore, the data souce are found from the novel itself. Those can be utterances, words, sentence, textually or contextually which are taken from Laskar Pelangi novel which contain about motivation. In this research, the writer does some sequences:

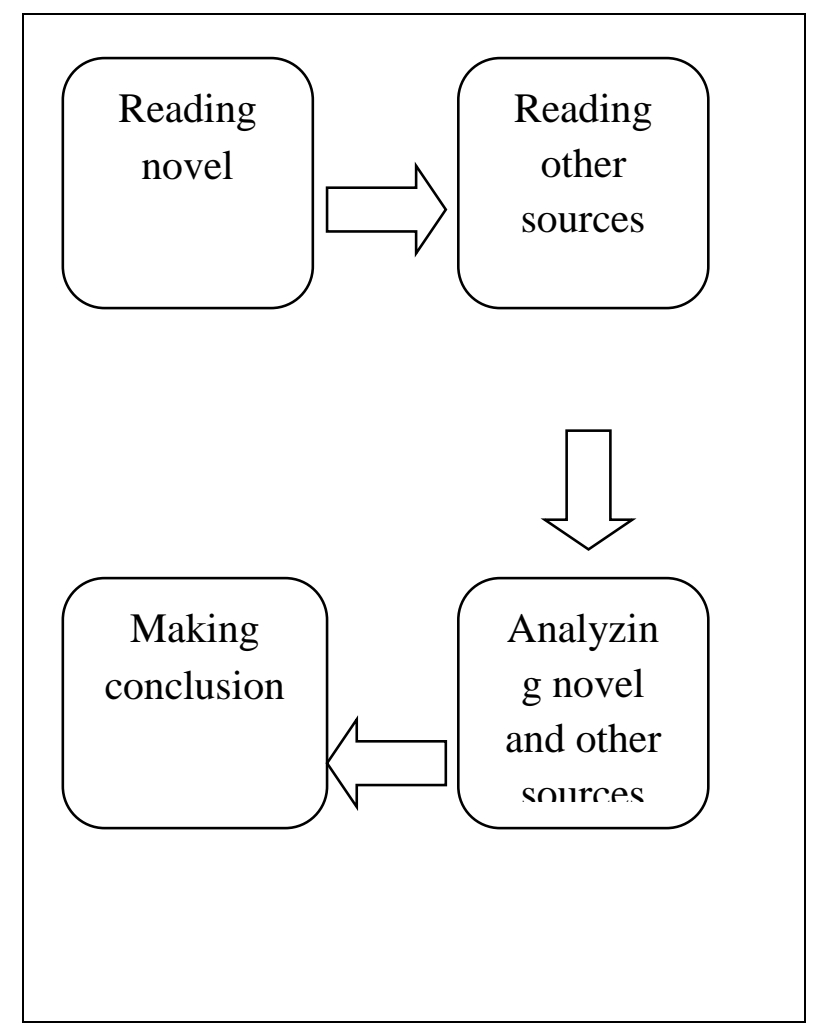

In this research, the writer uses documentation as technique of data collection. The data collection is taken from library by looking for data from any media. In this case, the writer reads the novel and analyzes the plot of story. The writer also looks for other information which is relevant with the problem. Afterthat, the technique of data analysis in this study is descriptive and the interpretation of the text is content analysis. It means the writer tries to describe some facts then analyzes novel to know the content of novel (Ratna, 2007: 8). 


\section{Discussion}

\section{Literary elements of Laskar Pelangi Novel}

\section{Character and characterization}

Based on Longman Advance Dictionary characterization is the way in which the qualities of a real person or thing are described (Longman Advanced American Digital Dictionary). In the novel, there are two ways in describing a character. There are two methods in describing the character in the novel, those are descriptive and dramatic. Character may be presented mainly through description and discussion, or in a more dramatic manner, by the author's simply reporting the character's speech and action. Characters are divided into two kinds, major character and minor character. Every story needs those characters to suppoort each other because each character cannot stand by itself. As Stanton said, most stories contain a central character, which is relevant to every event in the story; usually the events cause some change either in him, or in our attitude toward him (Stanton, 1965: 17).

The major character in Laskar Pelangi novel is Ikal. While the minor character in this novel are $\mathrm{Bu}$ Muslimah, Mr. Harfan, Lintang, Mahar, A Kiong, Trapani, Kucai, Sahara, Syahdan, Harun, Borek, A Ling, Tuk Bayan Tula, Bodenga, Floriana, A Miauw, Mrs. Friska, Mr. Zulfikar.

\section{Setting}

Stanton (1965: 18) said that the setting of a story is the environment of its events, the immediate world in which they occur. Usually, the description of setting was clearly viewed in the story, as if the reader lives in that place and feels what was in the story.

The setting of time in this novel is about 1970's. While generally all setting are located in Belitong. Those are Muhammadiyah School, PN (Perusahaan Negara) Timah School, Sinar Harapan Shop, Felicia Tree, 
Selumar Mountain, Fish Market, Lanun Island, Punai Anchorage Beach, National School yard, China Templem Tanjong Pandan, Zaal Batu and Post Office.

Plot

Plot is a series of events which intertwined accurately and form a plot that actuate the flow of story through complication into climax and resolution (Budianta, 2002: 86). The plot of this novel consists of exposition, rising action, climax, falling action and resolution.

Point of view

Point of view is way and or opinion used by author as medium to present figures, action, setting and some events that make a story in fiction work to reader. Thus, point of view is the way an aouthor tell the story, whether as a first person (as the subject), as a second person (you or they), or as the third person (story observer). 'In this novel, the author uses first person of "I" as point of view.

Style

Stanton (1965: 30) said that, style in literature is the author's manner of using language. Even if there are two authors who wrote a story which have some similarities in plot, setting, characters but they will be different from their style in telling a story. Andrea Hirata as an author of Laskar Pelangi novel has unique style. This novel is written simply and easily to be understood by the reader. The author also used some figurative languages to describe something.

Theme

Theme is something that used as the basic story, or something that become main problem in a story. The theme of Laskar Pelangi novel is the spirit to learn. 


\section{The motivation in learning presented in Laskar Pelangi novel}

In this part, the writer presents some sentences, utterances from Laskar Pelangi novel which indicate about learning motivation, something to motivate someone in learning, or the motive of someone wants to learn textually or contextually. Motivation divided into extrinsic and intrinsic, thus learning motivation of Laskar Pelangi novel also presented into extrinsic motivation.

\section{Extrinsic motivation}

1. To change the destiny

It was the motivation that Lintang's father passed away when he wanted to bring this son to school. He wanted a change in his family; he wanted his son not to be a poor fisherman like him. Lintang's father had a willing that his son had better future and life than him.

2. To enrich knowledge

It was truly the aim of someone learning something. He wants to enrich his knowledge that he had. All obstacles will not hamper him, when he has big willing to enrich his knowledge. It looks like what Lintang did. He was crazy of studying. He was never absent from school, even a big crocodile had blocked his trip, but he still wanted to go to school to get more knowledge.

3. To reach dream

Everybody has dream and ambition in life. Every person maybe has different ambition, for example a child has an ambition to be a politician, scientist, or even being a success business man. The inspiration of an ambition can be taken from any sources, probably from film, his environment, or maybe his skill. He studies hard to reach his dream. Previously, Ikal had an ambition to be a professional badminton player 
and a writer. Thus he trained his skill in playing badminton until he became a skilled badminton player, although finally, he had to change his ambitions because of his destiny did not bring him to be a famous badminton player.

\section{To please parents}

Being successful in learning is something that makes parents proud of their child. So as Lintang, he had big willing to make his parent happy and proud of him, thus he had to study hard and to be a good student.

5. To get scholarship

It is what we want up to now, studying hard and getting scholarship. Every student wishes to get a scholarship, whether it for studying abroad or for school fee. After so many years, Ikal had never studied he began studying hard to get scholarship studying abroad. He studied all the time without compromising. Everywhere and every time he studied, just because of getting scholarship.

\section{Intrinsic motivation}

\section{To create a creation}

Everybody is proud when his learning results something. When we have done our painting, we will feel satisfied, even when our painting is the most beautiful from others and got an appreciation although it just a condemnation. Laskar Pelangi students always compete to get the best creation in art subject. They wanted to be like Mahar who always had sparkling idea to create something new in every art subject.

2. To win a competition

Getting a prize or winning something is other motive that someone wants to study hard. He will be very satisfied when they had won that competition. So as, Laskar Pelangi students, they were very spirit in exercising for Independence Day carnival, they would like to bear down 
their rival PN School students. It was because of Mahar, who had inflated their spirit to show their best performance and win the competition whatever other people said about them.

3. To be a confident man

To be a confident man is sometimes a problem for some people. They sometimes feel not confident although only introducing his name in front of the class. They are very nervous facing many people in an occasion. Omitting this character was not too difficult, more exercises speaking in front of many people and little bit motivation to calm down our nervous are probably the keys of solving it.

The reason of Andrea Hirata took spirit of learning as theme of Laskar Pelangi novel

In this section, the writer would like to expose the reason Andrea Hirata wrote this novel, and spirit of learning as its theme. Here are some reasons which are taken from Laskar Pelangi the Phenomenon book.

\section{To break Melayunese stereotype}

There is a stereotype cohering Melayunese that they are lazy men. It is probably because Malaysia government policy gave special protection and peculiarity for Melayunese. Thus, up to now, they feel that they are more special than other and do not need to work hard. When he was interviewed by Nasrul Azwar a reporter from Bangka Belitung Tabloid about this stereotype he introspected himself and investigated people around him, then he said "Less or more this stereotype is true" (Karni, 2008: 153). But not at all of Melayunese are lazy. Laziness that result backwardness and poorness in Belitong which inspire Andrea and his friends struggle and conviced that learning is the most effective instrument to escape backwardness (Karni, 2008: 158). 
To motivate all students to be always fighting spirit

By writing his memoir when he was child, Andrea Hirata expects he can motivate all studnets to fight their spirit in learning, and reach their ambitions whatever their condition. Andrea told that the important thing is a strong character formation, in order to be optimistic to improve an expectation and dream (Karni, 2008:197). "Now, all educational values derived from Laskar Pelangi story will be spread through "Laskar Pelangi in action" (Karni, 2008:197)

To be a good idol in education

One of strength of Laskar Pelangi novel is that there are some figures that have role to awaken reader spirit in learning, such as Lintang who was never absent although so many obstacles hampered him. Andrea hopes that figures such a Lintang or $\mathrm{Bu}$ Muslimah who never beefed about their condition can be an idol in education. Karni (2008: 117) said that one of contributive values of Laskar Pelangi novel is its qualification to appear a real model among the country which merely loss a guidance figure.

\section{The influence of Laskar Pelangi story toward its reader}

It was really amazing only for three years, Laskar Pelangi novel has been reprinted for twenty six times. A wonderful story that makes this novel becomes best seller. this powerful novel has inspired and motivared the readers to realize how important learning, and resuscitate to be spirit in learning. Below are some opinions of Laskar Pelangi novel reader about the effect that they feel after they read it.

1. Andy F. Noya a presenter of Kick Andy Show, he commented that this novel was really awakening. He said "Anyone who read it would be 
motivated and feel guilty if he was not grateful about his life." (Hirata, 2008: cover).

2. Nico a university student in Bandung has felt the power of Laskar Pelangi story. Previously, he was a drug abuser. His parents have acceded asking him to rehab from using drug. But he stubbornly rejected it. After reading it, he realized and wanted to be rehab. Afterthat, he also wanted to finish his graduating paper. Nico in Karni (2008: 2) said that "I was shy to the struggle of the teacher figure in that novel, and I was shy to the struggle of the teacher figure in that novel, and /i was shy to Lintang, a poor child who had to stop his school because his father was died and less of money."

3. Laskar Pelangi novel also has become motivation to a teacher in Cirebon, namely Maisaroh. She is an honorary teacher in Pamijah State Elementary School in Cirebon. Now she does not really care about her sakary, how much she gets. After reading Laskar Pelangi novel, she is more spirit motivating her students, who almost of them are rattan plait labor children. Maisaroh's spirit is inspired by Bu Muslimah dedication, whose her salary and facility are far more apprehensive, but she can fight her students's spirit, until one of them had got master degree from Europe (Karni, 2008: 3).

\section{Conclusion}

After analyzing the novel "Laskar Pelangi" the writer is able to include as follow; (1) the literary elements of Laskar Pelangi Novel are (a) character and characterization (the major character in Laskar Pelangi novel is Ikal and a lot of minor characters), (b) the setting of time in this novel is about 1970's and generally all setting are located in Belitong, (c) the plot of 
this novel consists of exposition, rising action, climax, falling action and resolution, (d) the author uses first person of "I" as point of view, (e) the style of this novel is written simply and easily to be understood by the reader. The author also used some figurative languages to describe something, (f) the theme of Laskar Pelangi novel is the spirit to learn. (2) The motivations in learning presented in Laskar Pelangi novel are: extrinsic motivation (to change the destiny, to enrich knowledge, to reach dream, etc) and intrinsic motivation (to create a creation, to win a competition, and to be a confident man). (3) The reasons of Andrea Hirata took spirit of learning as theme of Laskar Pelangi novel are to break Melayunese stereotype, to motivate all students to be always fighting spirit, and to be a good idol in education. (4) the influences of Laskar Pelangi story toward its reader are Laskar Pelangi story has influenced a university student to rehab from abusing drug, and Laskar Pelangi story has taught teacher to teach sincerely.

\section{References}

Budianta, Melani. 2002. Membaca Sastra: Pengantar Memahamai Sastra untuk Perguruan Tinggi. Magelang: Indonesiatera

Dahar, Ratna Wilis. 1989. Teori Teori Belajar. Jakarta: Erlangga

Hirata, Andrea. 2008. Laskar Pelangi. Jogjakarta: Bentang

Hornby AS. 1987. Oxford Advance Learner's Dictionary of Current English. New York: Oxford University Press

Karni, Asrori S. 2008. Laskar Pelangi: the Phenomenon. Bandung: Hikmah.

Longman Team. 2003. Longman Dictionary of Contemporary English. UK: Latter Park Press.

Ratna, Nyoman Kutha. 2007. Teori, Metode dan Teknik Penelitian Sastra. Yogyakarta: Pustaka Pelajar.

Stanton, Robert. 1965. An Introduction to Fiction. New York: Holt, Rinehart and Winston irc.

www.dekisoegi.ohlog.com. On May 20, 2010 